\title{
Evaluation of hypermobility syndrome associated with vesico-ureteric reflux in children
}

\author{
Reza Shiari ${ }^{1,2^{*}}$, Reza Amir Askari ${ }^{1}$, Masumeh Mohkam,2 \\ From 18th Pediatric Rheumatology European Society (PReS) Congress \\ Bruges, Belgium. 14-18 September 2011
}

\section{Background}

Joint hypermobility Syndrome is an inherited disease of connective tissue with symptoms of musculoskeletal involvement. On the other hands, Idiopathic reflux occurs in approximately $1 \%$ of the children and cause kidney scar and hypertension.

\section{Aims}

Considering the etiology of hypermobility syndrome that is involvement of connective tissue as a result of a disruption in the synthesis of collagen, there is a possibility of other organs involvement such as urinary system which the structure of connective tissue plays an important role. The aim of this study was to determine the association of hypermobility syndrome with vesico-ureteric reflux in children.

\section{Materials and methods}

This research was performed on 70 children between 316 years old with vesico-ureteric reflux and 70 normal children as a case control study.

\section{Result}

There was an association between urinary tract infection and hypermobility syndrome $(\mathrm{P}=0.001)$. Urinary reflux had a significant relation with myalgia $(\mathrm{P} \leq .0 .026)$. There was an association between myalgia and arthralgia, with hypermobility syndrome $(\mathrm{P} \leq .0 .001)$ and $(\mathrm{P}=0.03)$ respectively. We found a significant association between vesico-ureteric reflux and hypermobility syndrome $(\mathrm{P} \leq 0.001)$.

\footnotetext{
* Correspondence: shiareza@yahoo.com

'Shahid Beheshti University of Medical Sciences, Mofid Children Hospital, Tehran-Iran
}

Full list of author information is available at the end of the article

\section{Conclusion}

Considering the significant relation of vesico-ureteric reflux and hypermobility syndrome, it's been recommended that children with hypermobility syndrome are better evaluated for urinary tract infection.

\section{Author details \\ ${ }^{1}$ Shahid Beheshti University of Medical Sciences, Mofid Children Hospital, Tehran-Iran. ${ }^{2}$ Pediatric Infectious Research Center (PIRC), Tehran-Iran.}

Published: 14 September 2011

doi:10.1186/1546-0096-9-S1-P240

Cite this article as: Shiari et al:: Evaluation of hypermobility syndrome associated with vesico-ureteric reflux in children. Pediatric Rheumatology 2011 9(Suppl 1):P240.

\section{Submit your next manuscript to BioMed Central and take full advantage of: \\ - Convenient online submission \\ - Thorough peer review \\ - No space constraints or color figure charges \\ - Immediate publication on acceptance \\ - Inclusion in PubMed, CAS, Scopus and Google Scholar \\ - Research which is freely available for redistribution \\ Submit your manuscript at www.biomedcentral.com/submit}

